\title{
Available Lysine Losses in Salt Soluble Proteins of Mackerel by Heating
}

\author{
Munehiko TANaKA*, Satoshi OKubo*, Kōsaku Suzuki*, \\ and Takeshi TAGUCHI \\ (Received April 10, 1981)
}

\begin{abstract}
Loss of available lysine in salt soluble proteins of mackerel meat was determined. It showed that loss of available lysine by heating was accelerated by the addition of reducing sugar and its loss rate increased as the moisture content decreased and the $\mathrm{pH}$ value increased. Activation energy for available lysine losses was $16 \mathrm{kcal} / \mathrm{mol}$ at $15 \%$ and $50 \%$ moisture levels, while $30 \mathrm{kcal} / \mathrm{mol}$ at $80 \%$ moisture level. Available lysine losses in salt soluble proteins of Pacific marlin and walleye pollack meats were also examined at the moisture content of $15 \%$. Activation energies were $18 \mathrm{kcal} / \mathrm{mol}$ and $15 \mathrm{kcal} / \mathrm{mol}$, respectively. There appeared no significant differences in the activation energy for available lysine loss among these fish species. It was observed that the loss rate of reducing sugar was always greater than that of available lysine in these reactions.
\end{abstract}

It is well-known that cooking and baking of meat results in the loss of essential amino acidsparticularly lysine due to the browning reaction. However, little information about the availability of lysine has been obtained as far as fish meat is concerned.

In the previous paper, it was revealed that the loss of available lysine in water soluble proteins of mackerel meat by heating was accelerated in the presence of reducing sugar, and the reactions followed the first order kinetics. ${ }^{1)}$ The rates of available lysine losses were affected by the heating temperature, $\mathrm{pH}$, and water content.

In this study, available lysine losses in salt soluble proteins of mackerel meat by heating were determined to compare with those of water soluble proteins. Furthermore, loss of available lysine of Pacific marlin and walleye pollack muscles was also investigated.

\section{Materials and Methods}

\section{Sample Preparation}

Mackerel Scomber japonicus in rigor was used. Walleye pollack Theragra chalcogramma and Pacific marlin Makaira mitsukurii were also used for comparison. The dressed fish (head, fins, viscera, and dark muscle were removed) were homogenized with $20 \mathrm{vol}$. (w/v) of $\mathrm{M} / 30$ phosphate buffer ( $\mathrm{pH} 7.5$ ) containing $0.6 \mathrm{M} \mathrm{KCl}$. After centrifugation, the supernatant was filtered through a No. 2 filter paper and 3 vol. of cold distilled water was added to precipitate the salt soluble protein out. The salt soluble protein was collected by centrifugation and dialyzed against cold water for 3 days. The dialyzed salt soluble protein was frozen in the shallow pans at $-20^{\circ} \mathrm{C}$, and freezedried.

The mixture of salt soluble protein with either D-glucose or D-glucose-6-phosphate (G6P) was prepared by the same manner reported in the previous paper. ${ }^{1)}$ An initial molar ratio of reducing sugar to lysine was adjusted to 0.388 and the moisture content of the sample to 15,50 , or $80 \%$.

\section{Heat Processing}

Samples were heated at temperatures and conditions as described below:

\section{pH: $5.4,6.5,7.7$}

Moisture content: $15,50,80 \%$

Heating temperatures and heating times: $80^{\circ} \mathrm{C} ; 30,60,120,180,240 \mathrm{~min}$ $100^{\circ} \mathrm{C} ; 15,30,45,60,120 \mathrm{~min}$ $120^{\circ} \mathrm{C} ; 5,10,20,30,45 \mathrm{~min}$

Heating samples was carried out in the same manner as described previously. ${ }^{1)}$

\section{Chemical Analyses}

Available lysine was determined by 2,4,6-trinitrobenzenesulfonic acid (TMBS) method. ${ }^{2)}$ Free glucose was measured by the Glucostat reagent (Worthington Chemical Corp.) and free G6P was enzymatically assayed according to the method of HoHORST. ${ }^{3)}$

* Tokyo University of Fisheries, Konan-4, Minato, Tokyo 108, Japan (田中宗彦・大久保智・鈴木尿 策・田口武：東京水産大学)。 


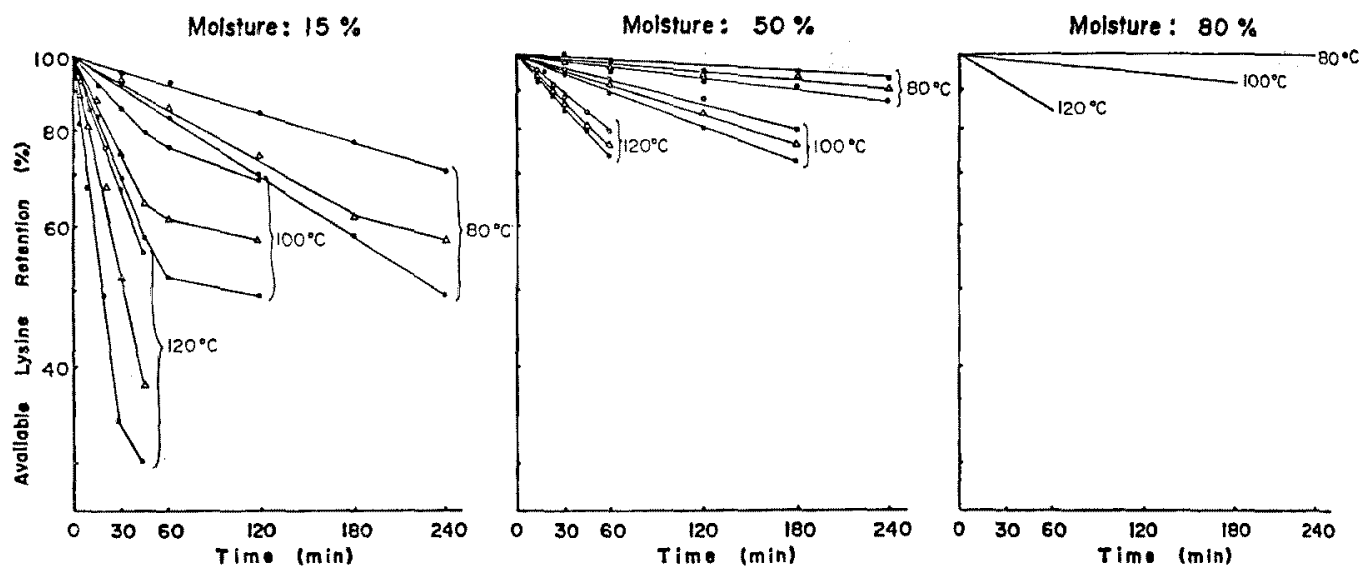

Fig. 1. Percent retention of available lysine in salt soluble protein of mackerel meat heated at $80,100,120^{\circ} \mathrm{C}$ in the presence of glucose. $\mathrm{G} / \mathrm{Lys}$ ratio was 0.388 .

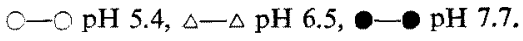

\section{Results and Discussion}

\section{Loss of Available Lysine}

Fig. 1 presents the effects of heating temperature and $\mathrm{pH}$ on the retention of available lysine in the salt soluble proteins to which glucose was added at the moisture contents of 15,50 and $80 \%$. It is obvious from this Figure that the retention of available lysine became smaller as the heating temperature or $\mathrm{pH}$ increased and the moisture content decreased.

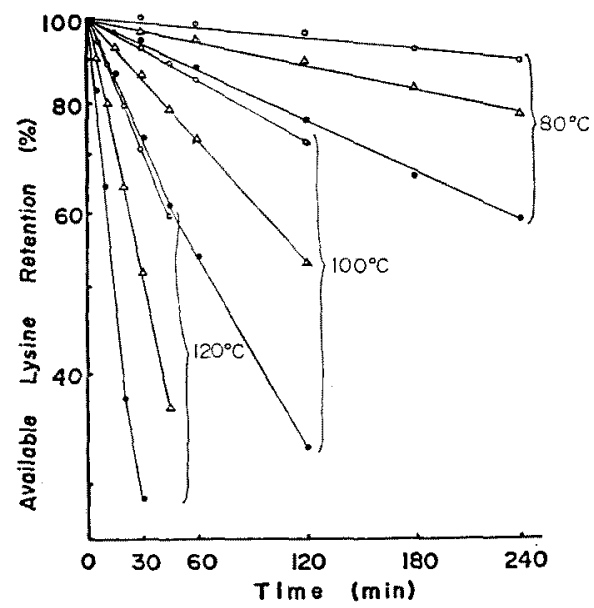

Fig. 2. Percent retention of available lysine in salt soluble protein of mackerel meat heated in the presence of glucose-6-phosphate. Moisture content was adjusted to $15 \%$ and $\mathrm{G} 6 \mathrm{P} / \mathrm{Lys}$ ratio was 0.388 .

$\bigcirc-\mathrm{pH} 5.4, \triangle-\triangle \mathrm{pH} 6.5$,

$\mathrm{pH} 7.7$
Without the addition of the reducing sugar to these systems, however, available lysine losses in salt soluble proteins of mackerel meat by heating were quite small. The maximum loss approximately $15 \%$ was observed when the sample with moisture content of $15 \%$ was heated at $120^{\circ} \mathrm{C}$ for 240 min. At 50 or $80 \%$ moisture level, losses of availablel lysine were not detected in any samples.

Effects of heating temperature and $\mathrm{pH}$ on the retention of available lysine in the presence of $\mathrm{G} 6 \mathrm{P}$ are shown in Fig. 2. The rates of available lysine losses in the presence of G6P was somewhat larger than those in the presence of glucose at $15 \%$ moisture level. At these reactions, the overall pattern of available lysine losses in the salt soluble proteins of mackerel meat is quite similar to that in the water soluble proteins. ${ }^{1>}$

Table 1. Activation energy for available lysine losses at 15,50 , and $80 \%$ moisture levels in the presence of reducing sugar. The molar ratio of reducing sugar to lysine was 0.388

\begin{tabular}{cccc}
\hline \multirow{2}{*}{ pH } & $\begin{array}{c}\text { Moisture } \\
\text { content } \\
(\%)\end{array}$ & \multicolumn{2}{c}{$\begin{array}{c}\text { Activation energy } \\
(\mathrm{kcal} / \mathrm{mol})\end{array}$} \\
\cline { 3 - 4 } & & Glucose & $\begin{array}{c}\text { Glucose-6- } \\
\text { phosphate }\end{array}$ \\
\hline \multirow{3}{*}{5.4} & 15 & 15.2 & 20.8 \\
& 50 & 16.3 & \\
& 80 & 30.9 & \\
6.5 & 15 & 16.0 & 21.0 \\
& 50 & 16.0 & \\
& 80 & 29.5 & \\
& 15 & 17.5 & 20.4 \\
& 10 & 15.4 & \\
& 80 & 26.8 & \\
\hline
\end{tabular}


Table 1 gives the activation energies for available lysine losses. The activation energy was calculated from the available lysine loss rate constants using the ARRHENIUS equation. It is worthy of note that there was almost no difference in the activation energy for available lysine loss by heating in the presence of glucose between 15 and $50 \%$ moisture levels as well as the $\mathrm{pH}$ values. On the contrary, the activation energy increased almost double by increasing the moisture content to $80 \%$. The activation energy for available lysine loss in the presence of G6P was approximately $20 \mathrm{kcal} / \mathrm{mol}$ regardless of $\mathrm{pH}$. Those values are quite close to those for the water soluble proteins of mackerel meat. ${ }^{1)}$ From these results described so far, it can be concluded that the salt soluble proteins and water soluble proteins of mackerel meat lose the available lysine by heating in an analogous manner.

Fig. 3 shows the retention of available lysine in salt soluble proteins of Pacific marlin and walleye pollack meats. It is obvious from this Figure that there was only a slight difference in the loss of available lysine among these fish species and mackerel. From the available lysine loss rate constants, the activation energies for Pacific marlin and walleye pollack salt soluble proteins were $18.8 \mathrm{kcal} / \mathrm{mol}$ and $15.1 \mathrm{kcal} / \mathrm{mol}$, respectively. Those values are fairly close to the activation energy for the available lysine loss of mackerel salt soluble proteins. Although it is well-known that the heat stability
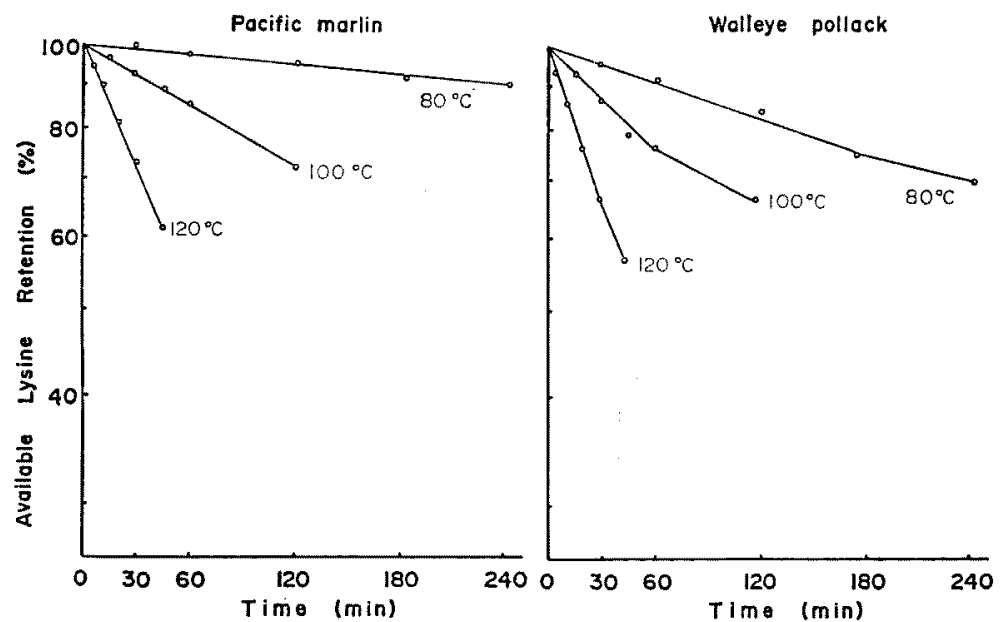

Fig. 3. Percent retention of available lysine in salt soluble proteins of Pacific marlin and walleye pollack meats heated in the presence of glucose at $\mathrm{pH} 6.5$. Moisture content was adjusted to $15 \%$ and $\mathrm{G} / \mathrm{L} y \mathrm{~s}$ ratio was 0.388 .
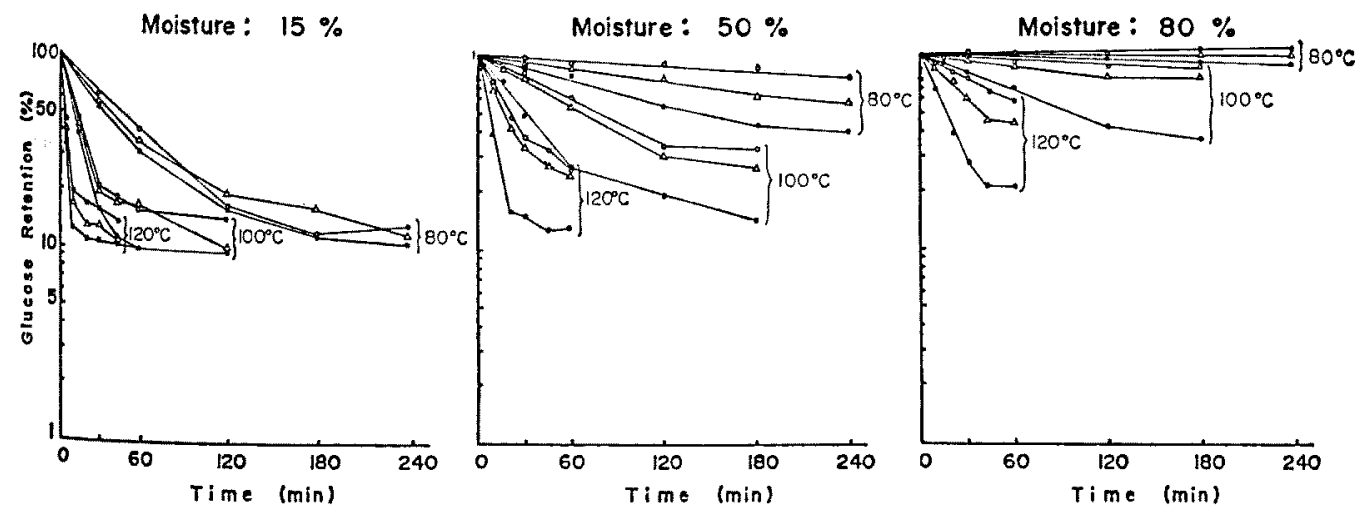

Fig. 4. Percent retention of glucose as a function of time and temperature. Moisture content was adjusted to 15,50 , or $80 \%$, and $\mathrm{G} / \mathrm{Lys}$ ratio was 0.388 . $\bigcirc \mathrm{pH} 5.4, \Delta-\Delta \mathrm{pH} 6.5, \bullet \mathrm{pH} 7.7$ 
of Pacific marlin protein is greater than that of walleye pollack protein, ${ }^{4, b}$ there seemed no significant difference in the stability of available lysine in the protein between those fish species.

\section{Loss of Reducing Sugar}

Fig. 4 and 5 show the fractional losses of added glucose and G6P. Though the degradation of the reducing sugar as well as the available lysine was the first order reaction at the initial stage of heating, losses of glucose or G6P were considerably larger than those of available lysine when compared under the identical conditions. It was suggested that the reducing sugar reacts not only to the $\varepsilon$-amino group of lysine but also to other active groups at side chains of the protein molecule.

In Table 2, activation energies for glucose and G6P losses are presented. Activation energy for G6P loss was larger than that for glucose loss. There was a similar tendency for the activation energy for the reducing sugar reactions to both water soluble proteins and salt soluble proteins.

From the fact that the available lysine losses of

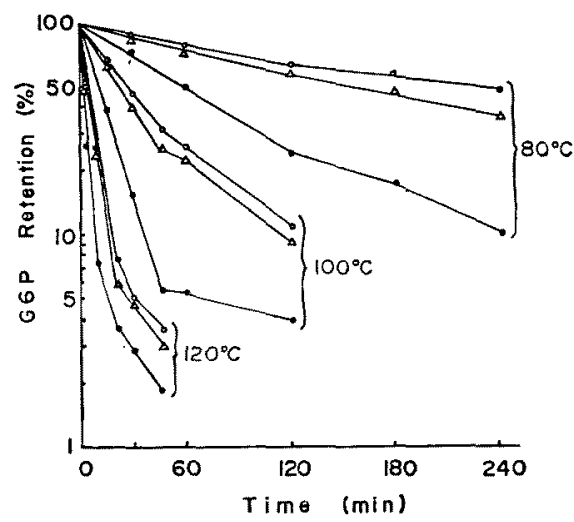

Fig. 5. Percent retention of glucose-6-phosphate as a function of time and temperature. Moisture content was adjusted to $15 \%$ and $\mathrm{G} 6 \mathrm{P} / \mathrm{Lys}$ ratio was 0.388 .

$\bigcirc-0 \mathrm{pH} 5.4, \Delta-\Delta \mathrm{pH} 6.5, \bullet-\mathrm{pH}$ 7.7.
Table 2. Activation energy for glucose and glucose6-phosphate losses at 15,50 , and $80 \%$ moisture level

\begin{tabular}{|c|c|c|c|}
\hline \multirow{2}{*}{$\mathrm{pH}$} & \multirow{2}{*}{$\begin{array}{l}\text { Moisture } \\
\text { content } \\
(\%)\end{array}$} & \multicolumn{2}{|c|}{$\begin{array}{l}\text { Activation energy } \\
(\mathrm{kcal} / \mathrm{mol})\end{array}$} \\
\hline & & Glucose & $\begin{array}{l}\text { Glucose-6- } \\
\text { phosphate }\end{array}$ \\
\hline \multirow{3}{*}{5.4} & 15 & 16.7 & 24.7 \\
\hline & 50 & 21.0 & \\
\hline & 80 & 24.3 & \\
\hline \multirow{3}{*}{6.5} & 15 & 16.1 & 23.8 \\
\hline & 50 & 21.9 & \\
\hline & 80 & 27.6 & \\
\hline \multirow{3}{*}{7.7} & 15 & 16.5 & 21.7 \\
\hline & 50 & 20.7 & \\
\hline & 80 & 25.3 & \\
\hline
\end{tabular}

salt soluble proteins of mackerel meat by heating in the presence of reducing sugar, on the whole, were comparable to those of the water soluble proteins, it appeared that the reaction of lysine to the reducing sugar was probably independent of the protein structure. However, the stability of available lysine in the salt soluble proteins of mackerel meat is somewhat smaller than that in the water soluble protein fraction.

\section{References}

1) M. Tanaka, S. Okubo, K. Suzuki, and T. TAGUCHI: Bull. Japan. Soc. Sci. Fish., 46, 15391543 (1980).

2) M. L. KAKADE and I. E. LIeNER: Analytical Biochem., 27, 273-280 (1969).

3) H. J. HoHorsr: in "Methods of Enzymatic Analysis" (ed. by H. U. BergmeYer), Academic Press, New York, 1973, pp. 134-138.

4) H. UchiYama, N. Katoh, Y. Kudo, and K. ARAI: Bull. Japan. Soc. Sci. Fish., 44, 491-497 (1978).

5) T. Taguchi, K. Kikuchi, M. Ogun, M. Tanaka, and K. Suzuki: Bull. Japan. Soc. Sci. Fish., 44, 1363-1366 (1978). 